Studies in African Linguistics

Volume 37, Number 1, 2008

\title{
NEUTRALIZATION OF CONTRAST IN THE VOWEL SYSTEM OF URHOBO*
}

\author{
Rose O. Aziza \\ Delta State University
}

\begin{abstract}
Urhobo, a South Western Edoid language of the Niger-Congo family, is spoken in Delta State, Nigeria. In the synchronic phonology of the language, there are seven surface vowels: [i, e, $\varepsilon, a, o, o, u]$, but the behavior of some vowels, especially $e, o, \varepsilon$, is sometimes at variance with their expected vowel behavior, indicating that there may be abstract underlying vowels $* / \mathrm{I}, \mathrm{U}, \mathrm{\partial} /$ which have merged with /e, o, $\varepsilon /$. The result, when compared with sister languages such as Degema and Isoko, is that the Urhobo system appears quite complex. The focus of this paper is showing that abstract underlying */I, $\mathrm{U}, \mathrm{\partial} /$, which are Proto Edoid vowels, still have an effect in the synchronic phonology: thus, /I, e/ become [e], /u, $\mathrm{o} /$ become $[\mathrm{o}]$, and $/ \mathrm{a}, \varepsilon /$ become $[\varepsilon]$ and possibly [a]. When we account for the 'awkward' behavior of apparent /e, o, $\varepsilon /$, the Urhobo vowel system is clear and straightforward.
\end{abstract}

The Edoid languages make up a sub-branch of the West Benue-Congo branch of Niger-Congo, and are spoken in the southern part of Nigeria. They are classified into four co-ordinate groups, namely Delta Edoid (DE), North Central Edoid (NCE), North Western Edoid (NWE), and South Western Edoid (SWE) (Elugbe 1973, 1989). The languages have vowel systems consisting of between seven and ten vowels. The Proto-Edoid (PE) vowels are */i, I, e, $\varepsilon, \partial, \mathrm{a}, \supset, \mathrm{o}, \mathrm{u}, \mathrm{u} /$. Languages which have fewer than ten vowels are said to have reduced their systems through the merging of certain vowels with others. Lindau (1975), using acoustic

\footnotetext{
* This paper has benefited from the various reviewers' comments and I am immensely grateful. All uncorrected errors are those of the author.
} 
perturbation theory, identifies two common patterns of vowel merging, namely / $/$ / merging with /e/ for acoustic reasons, and /u/ merging with /o/ for reasons of structural pressure, resulting in an earlier nine-vowel system becoming reduced to a seven-vowel system. Williamson (1983) has also reported that PE */a/ has merged with $/ e, \varepsilon, a /$ in a number of languages within the Niger-Congo family, and that where $* / 2 /$ has merged with $/ \mathrm{a} /$, the vowel becomes neutral if the language maintains a harmony system.

Of the Edoid languages, only Degema, a DE language, still has contrasts involving all ten vowels (Fulop, Kari \& Ladefoged 1998). Elugbe (1989) reports that the other languages have reduced their systems in one of three ways:

a. in nine-vowel systems, there is no /a/; e.g. Isoko (a SWE language);

b. in eight-vowel systems, there are no /o, I/, e.g. Ibilo (a NWE language);

c. in seven-vowel systems, there are no /a, I, U/, e.g. Urhobo (a SWE language).

Vowel harmony is a very common phenomenon in Edoid languages and the feature advanced tongue root, i.e., [+ATR] or retracted tongue root, i.e., [-ATR] is a common label used to describe it. The PE vowel patterns divide into the following two sets:

(1) Proto Edoid (PE) Vowels

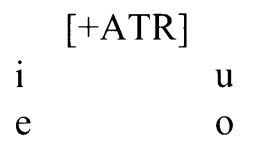

ว

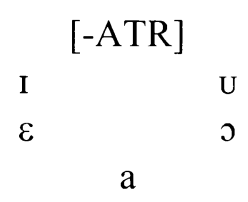

a

Our purpose in this paper is to account for vowel behavior in the synchronic grammar of Urhobo.

\section{Previous Studies on the Vowel Systems of SWE Languages.}

SWE is made up of five languages: Eruwa, Isoko, Okpẹ, Urhobo, and Uvwiẹ. Urhobo is the largest in the group, and is commonly spoken as a first or second language within the SWE area.

Hoffman (1973) examines the vowel system of Okpe and, based on vowel harmony patterns displayed in various grammatical structures derived from verb root vowels, recognizes nine phonemic vowels, i.e., /i, I, e, $\varepsilon, \mathrm{a}$, 。, o, u, u/, al- 
though there are only seven surface vowels, i.e., [i, e, $\varepsilon$, a, o, o, u]. The two vowels $/ \mathrm{I}, \mathrm{U} /$ are said to have become surface $[\mathrm{e}, \mathrm{o}]$ respectively. Following Hoffman, Omamor (1973) reports a similar occurrence in Uvwie, and Omamor (1988) compares the vowel systems of both Okpe and Uvwiẹ, suggesting a regrouping of Okpe and Uvwie vowels on the basis of two overriding features: (i) the "advanced" (our [+ATR]) or "unadvanced" (our [-ATR]) harmony set to which they inherently belong and (ii) the height feature which separates them into a "high" set and a "low" set. However, although both linguists rightly observe that $/ \varepsilon /$, a member of the "unadvanced" set, sometimes alternates with /a/ as its "advanced" counterpart suffix in certain constructions, no attempt is made to explain the apparent violation of the co-occurrence restriction.

Donwa-Ifode (1989) examines vowel behavior in nouns in Eruwa and Isoko and reports that the languages have nine vowels each. She also suggests that $\mathrm{PE} * / \mathrm{\partial} /$ has merged with $/ \mathrm{a} /$ and $/ \varepsilon /$ in both languages because $/ \mathrm{a} /$, a typical [-ATR] vowel, sometimes occurs in prefix position where a [+ATR] vowel is expected and $/ \varepsilon /$, another [-ATR] vowel, sometimes occurs in stem position where a [+ATR] vowel is expected.

Studies of Urhobo vowels also exist in the literature, among which are Kelly (1969), Welmers (1969), Elugbe (1973, 1989,1991), Aziza (1994, 1997). Kelly (1969) examines vowel patterning in the Urhobo noun and, based on the quality of the plural marker, he recognizes two sets of vowels: those that form their plural by changing the initial vowel to [e] which belong to Group 1, and those that change to [i] which belong to Group 2. The vowels in his Group 1 are /a,, , $\varepsilon, \mathrm{o}$, e/ while those in Group 2 are /o, e, u, i/. He also recognizes three degrees of height for each group as follows:

$\begin{array}{lll} & \text { Group 1 } & \text { Group 2 } \\ \text { Top: } & \text { e, o } & \text { i, u } \\ \text { Middle: } & \varepsilon, 0 & \text { e, o } \\ \text { Bottom: } & \text { a } & \varepsilon, \text { o }\end{array}$

All linguists who have worked on Urhobo vowels recognize the presence of [ATR] harmony particularly in the verbal system.

In this work, we attempt a proper account of Urhobo vowels in both the verb and in the noun, as well as in their phrasal combinations. In particular, we examine the behavior of $e, o, \varepsilon$ in the synchronic grammar, seeking to determine whether there are abstract underlying vowels */I, U, a/ which may be responsible for the unpredictable behavior of the surface vowels in certain positions. We note 
that synchronic vowels $e$, $o$ which one would suppose to be mid [+ATR] vowels sometimes behave as high [-ATR] vowels, while the synchronic vowel $\varepsilon$ which one would suppose to be a mid [-ATR] vowel sometimes occurs where a [+ATR] vowel is expected. The study will show that although the surface merging of vowels is complete and there is absolute neutralization of contrast between the merged vowels in the synchronic system, the underlying features of the lost vowels come into play in the phonological patterning of surface vowels, thereby making the vowel system appear complex.

Urhobo has the following syllables: V, CV, and CCV. Tone is significant both lexically and grammatically (cf. Elugbe 1973, 1989, Aziza 1997, 2003). Only vowels bear tones and they are marked in our examples as follows: [ ] = Low tone $\left.(\mathrm{L}),{ }^{\prime}\right]=$ High tone $(\mathrm{H})$ while the contour tones are a combination of these. The downstepped $\mathrm{H}$ (Mid) is left unmarked.

\section{The Vowel System of Urhobo.}

At the phonetic level, Urhobo has the following seven vowels [i, e, $\varepsilon, \mathrm{a}, \mathrm{\jmath}, \mathrm{o}, \mathrm{u}]$. The orthographic equivalents $i, e, e, a, o, o, u$ are used for writing the language.

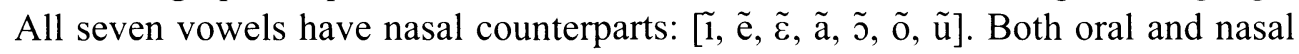
vowels pattern alike in the various grammatical structures and so are not given separate treatments. In addition, every vowel in the environment of a nasal segment is automatically nasalized, and such is not reflected in our examples. For a fuller discussion of nasality in Urhobo see Aziza (2002).

In Urhobo, both [ATR] harmony and vowel height play important roles in how the vowels of nouns and verbs pattern in various grammatical structures. Based on available data, the seven vowels pattern as in (3) in their harmonic and height behavior. Lowered indices are used after $/ \mathrm{e}, \varepsilon, \mathrm{o} /$ to reflect the actual phonetic forms in our examples.

\begin{tabular}{|c|c|c|c|}
\hline \multirow[b]{2}{*}{ High } & \multicolumn{2}{|c|}{ Set $1[+\mathrm{ATR}]$} & Set 2 [-ATR] \\
\hline & $\mathrm{i}$ & $\mathrm{u}$ & $\mathrm{e}_{2}$ \\
\hline Mid & $\mathrm{e}_{1}$ & $\mathrm{O}_{1}$ & $\varepsilon_{2}$ \\
\hline Low & & & \\
\hline
\end{tabular}

Henceforth, in referring to these vowel sets, we refer to them in terms of [+ATR] and [-ATR], referring to their phonological behavior, not their surface phonetic realisation. 
We notice that the vowels /e, o/ which are typical mid [+ATR] vowels sometimes behave as high [-ATR] vowels, i.e., $\left[\mathrm{e}_{2}, \mathrm{o}_{2}\right]$, while the typical mid [-ATR] front vowel $/ \varepsilon /$ sometimes co-occurs with $[+\mathrm{ATR}]$ vowels, i.e. [ $\left.\varepsilon_{1}\right]$. One basic characteristic of the vowel system of this language is that vowel sequences are not permitted at the surface level. Therefore, whenever two vowels occur in a sequence, one of the vowels either deletes or becomes a nonsyllabic glide. The typical high vowels $/ \mathrm{i}, \mathrm{u} /$ do not delete; they become glides: [j] for the front vowel $/ \mathrm{i} /$ and $[\mathrm{w}]$ for the back vowel $/ \mathrm{u} /$. Interestingly, the vowels $\left[\mathrm{e}_{2}, \mathrm{o}_{2}\right]$ consistently behave like the obvious high vowels in always becoming nonsyllabic glides $[\mathrm{j}, \mathrm{w}]$ respectively whenever another vowel follows them. All other vowels including $\left[\mathrm{e}_{1}, \mathrm{o}_{1}\right]$ occurring in a sequence can be deleted based on morpho-phonemic considerations. In addition, $\left[\mathrm{e}_{2}, \mathrm{O}_{2}\right]$ consistently select [-ATR] affixes instead of the [+ATR] affixes selected by $\left[\mathrm{e}_{1}, \mathrm{o}_{1}\right]$. There are also two different patterns of behavior for $/ \varepsilon /:\left[\varepsilon_{1}\right]$ consistently occurs in the environment of [+ATR] vowels, and $\left[\varepsilon_{2}\right]$ consistently selects [-ATR] affixes.

In what follows, we shall examine the behavior of $/ e, o, \varepsilon /$ in a number of grammatical structures involving verbs and nouns.

\section{The Behavior of $e, o, \varepsilon$ in Verbs.}

The basic structure of the Urhobo verb is monosyllabic, i.e., CV or CCV. Urhobo vowels are presented in monosyllabic verb roots in (4) below. Note the occurrence of $\left[\mathrm{e}_{2}, \mathrm{o}_{2}\right]$ as phonological [-ATR] verb root vowels and of $\left[\varepsilon_{1}\right]$ as a $[+\mathrm{ATR}]$ verb root vowel.

\begin{tabular}{|c|c|c|c|}
\hline \\
\hline \multicolumn{2}{|c|}{ a. [+ATR] vowels } & b. $[-A]$ & vowels \\
\hline sì & 'write, pull' & $\mathrm{rè}_{2}$ & 'eat' \\
\hline sè $_{1}$ & 'call, read' & $\int \grave{\varepsilon}_{2}$ & 'sell' \\
\hline$\gamma \check{\tilde{\varepsilon}}_{1}$ & 'be foolish' & $\mathrm{Co}_{2}$ & 'steal' \\
\hline cò & 'steal' & kpว̀ & 'dry up' \\
\hline kù & 'pour' & sà & 'shoot' \\
\hline
\end{tabular}

In grammatical constructions, affixes and other clitics such as monosyllabic pronouns that accompany verbs usually have two phonetic shapes, because they have to harmonize with the root vowel. In this section, we shall examine the derivation of the infinitive form, verb + object constructions, and constructions for the present, past and future tense in order to reveal the behavior of Urhobo vow- 
els, especially /e, o, $\varepsilon /$, as evidence for the existence of abstract underlying vowels $* / \mathrm{I}, \mathrm{U}, \mathrm{\partial} /$. As will be noticed in our examples, there is consistency in the behavior of the vowels: $\left[\mathrm{e}_{1}, \mathrm{o}_{1}\right]$ as root vowels consistently behave as typical nonhigh [+ATR] vowels while $\left[\mathrm{e}_{2}, \mathrm{o}_{2}\right.$ ] consistently behave as high [-ATR] vowels. Also, $\left[\varepsilon_{1}\right]$ consistently behaves as a $[+\mathrm{ATR}]$ vowel while $\left[\varepsilon_{2}\right]$ consistently behaves as a [-ATR] vowel. ${ }^{\text {' }}$

3.1. The infinitive. The verb derives its infinitive form by adding a prefix vowel $E$ - to the root. The variants of this prefix are: $e$ - for [+ATR] verbs and $\varepsilon$ - for [ATR] verbs. In addition, if the vowel of the verb is a high vowel, a suffix $-O$ (also in two phonetic shapes: $-o$ for [+ATR] roots and $->$ for [-ATR] roots) is also added. The addition of the suffix automatically creates the environment for the high root vowel to become a nonsyllabic glide. In the examples in (5) below, notice that while $\left[\mathrm{e}_{1}, \mathrm{o}_{1}, \varepsilon_{1}\right]$ select e-, the prefix vowel for [+ATR] roots, $\left[\mathrm{e}_{2}, \mathrm{o}_{2}, \varepsilon_{2}\right]$ select $\varepsilon$-, the prefix vowel for [-ATR] roots. Moreover, $\left[\mathrm{e}_{2}, \mathrm{o}_{2}\right]$ take a suffix vowel like the typical high vowels $[\mathrm{i}, \mathrm{u}]$ and select the variant $\rightarrow$ like the typical [-ATR] vowels. This is an indication that there are underlying vowels $* / \mathrm{r}, \mathrm{U}, \mathrm{a} /$ which may have become surface $\left[\mathrm{e}_{2}, \mathrm{o}_{2}, \varepsilon_{1}\right]$ respectively in the system.

a. [+ATR] verb roots

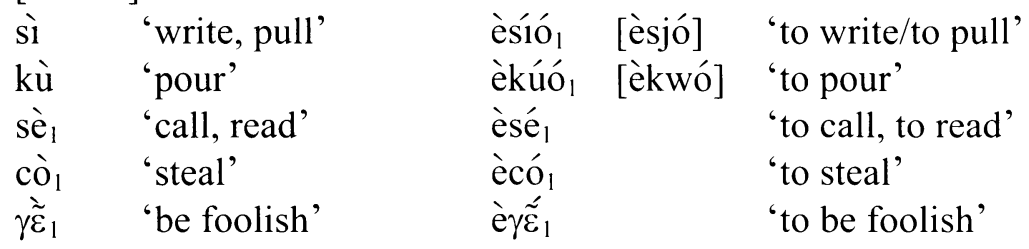

' Each monosyllabic subject or object pronoun is realized in two phonetic shapes to agree with the $[$ ATR $]$ harmony requirements of the verb stem vowel. The pronouns are listed below:

\begin{tabular}{|c|c|c|c|c|c|c|c|}
\hline & \multicolumn{4}{|c|}{ Subject Pronouns } & \multicolumn{3}{|c|}{ Object Pronouns } \\
\hline & $S g$ & & $P l$ & & $S g$ & & $P l$ \\
\hline & [+ATR $]$ & {$[-\mathrm{ATR}]$} & [+ATR] & [-ATR] & [+ATR] & {$[-\mathrm{ATR}]$} & \\
\hline $1^{\text {st }}$ & $\mathrm{mi}$ & $\mathrm{me}_{1}$ & àvárẽ $\tilde{\tilde{e}}_{2} / \mathrm{me}_{1}$ & àvárẽ $2 / \mathrm{ma}$ & $v_{1}$ & $v \varepsilon_{2}$ & àváre, \\
\hline $2^{\text {nd }}$ & $\mathrm{wo}_{1}$ & wo & $\grave{o}_{2}$ wàuá / we & $\grave{o}_{2}$ wàvắ / wa & $\mathrm{we}_{1}$ & $\mathrm{w} \varepsilon_{2}$ & $\mathrm{O}_{2}$ wàuắ \\
\hline $3^{\text {rd }}$ & $\mathrm{o}_{1}$ & 0 & àjè $\tilde{e}_{2}$ & $\grave{a ̀ j e ̀ ̀ ~}_{2}$ & $\mathrm{ro}_{\mathrm{I}}$ & ro & $\grave{a j j e ̀ ~}_{2}$ \\
\hline
\end{tabular}


b. $[-\mathrm{ATR}]$ verb stems

\begin{tabular}{|c|c|c|c|c|}
\hline $\mathrm{rè}_{2}$ & 'eat' & Èrió & [غ̀rjo] & 'to eat' \\
\hline & 'trade (vb)' & غ̇cuó & [Ècwo] & 'to trade' \\
\hline$E_{2}$ & 'sell' & $\grave{\varepsilon} \int^{\prime} \varepsilon_{2}$ & & 'to sell' \\
\hline & 'plant' & $\dot{\varepsilon} \mathrm{k} \tilde{\jmath}$ & & 'to plant' \\
\hline & 'shoot' & Èsá & & 'to shoot' \\
\hline
\end{tabular}

3.2. Verb + object. If the verb takes a noun object, since every noun begins with a vowel prefix, the vowel of the verb either becomes a nonsyllabic glide if it is high or it deletes if it is nonhigh. Here again, $\left[\mathrm{e}_{2}, \mathrm{o}_{2}\right]$ behave like the typical high vowels $[i, u]$, supporting the claim of the existence of underlying vowels $* / I, U /$ that have become $\left[\mathrm{e}_{2}, \mathrm{o}_{2}\right]$ respectively. Note the co-occurrence of $\left[\varepsilon_{1}\right]$ with [+ATR] vowels in the word for 'rope' in (6a). We shall return to this later.
a. $[+\mathrm{ATR}]$ verbs
si + úrùhré,
[sjúrùhré]
'pull a rope'
kù $+\grave{e}_{\text {lvrì }}$
[kwèuri]
'pour oil'
sè $_{1}+$ óàrè
[sófàrè]
'call a man'
$\mathrm{cò}_{1}+\mathrm{e}_{1} \mathrm{kpù}$
[cékpù]
'steal a bag'
vìํำ + ómó
[vjómó]
'give birth to a child'

b. [-ATR] verbs

\begin{tabular}{|c|c|c|}
\hline $\mathrm{rè}_{2}+\mathrm{jon}^{\prime} \dot{\varepsilon}_{2}$ & [rjòn'́] & 'eat yam' \\
\hline $\mathrm{sò}_{2}+$ une $_{1}$ & [swùnè] & 'sing a song' \\
\hline $\int \grave{\varepsilon}_{2}+\grave{\mathrm{e}}_{2} \mathrm{ymá}$ & [ ènmá] & 'sell clothes' \\
\hline kì + iŕrbó & [kìríibó] & 'plant pepper' \\
\hline$\grave{a}+\grave{o}_{1} h_{u o ́}$ & [sòhwó] & 'shoot a person' \\
\hline
\end{tabular}

3.3. Constructions in the present tense. The simple present or habitual tense is marked by a floating high tone that is realized on the final vowel of the subject. If the subject already ends on a low tone, a low-high contour is created, otherwise there is a perceivably lengthened high tone if the subject ended on a high tone. What is of interest to us here is the behavior of the vowels. Both subject and object monosyllabic pronouns must agree in [ATR] with the vowel of the verb root. Where the verb takes a noun object, as mentioned above, the environment is created for either glide formation or vowel elision to take place. In the examples below, note that whereas $\left[\mathrm{e}_{1}, \mathrm{o}_{1}, \varepsilon_{1}\right]$ as root vowels select [+ATR] affixes, $\left[\mathrm{e}_{2}, \mathrm{o}_{2}, \varepsilon_{2}\right]$ select [-ATR] affixes and also $\left[\mathrm{e}_{2}, \mathrm{o}_{2}\right]$ become nonsyllabic glides rather than un- 
dergo vowel elision as $\left[\mathrm{e}_{1}, \mathrm{o}_{1}\right]$ do. Note too that the allomorphs of the first person singular subject pronoun, $m I$, i.e., $m i$ with [+ATR] verbs and $m e$ with [-ATR] verbs correspond to Isoko $m i$ and $m I$ respectively; this is another indication of the merging of $* / \mathbf{I} /$ with $[\mathrm{e}]$ in Urhobo.

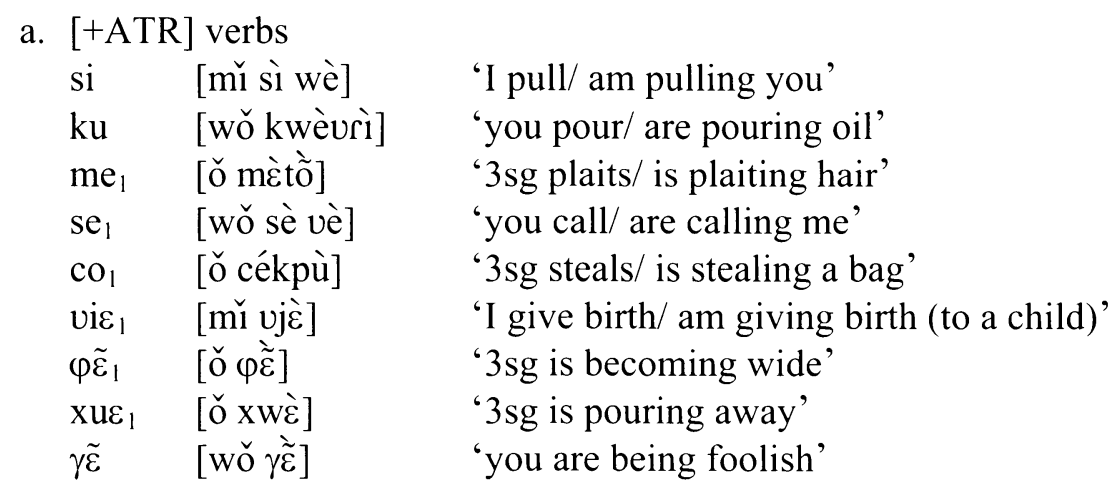

b. [-ATR] Verbs

\begin{tabular}{|c|c|c|}
\hline $\mathrm{re}_{2}$ & [wǒ rè vè] & 'You are eating me' \\
\hline$s \tilde{e}_{2}$ & [mě sè w⿳亠े] & 'I am rejecting/ denying you' \\
\hline $\mathrm{CO}_{2}$ & [wǒ cwèki] & 'You trade/ are trading' \\
\hline $\mathrm{SO}_{2}$ & [ว̌ sò vÈ] & ' 3 sg is singing (about) me' \\
\hline $\int \varepsilon_{2}$ & [ǒ fènmá] & ' $3 \mathrm{sg}$ sells/ is selling clothes' \\
\hline$\varphi \varepsilon_{2}$ & {$[\check{\partial} \varphi \grave{\varepsilon}]$} & ' $3 \mathrm{sg}$ is urinating' \\
\hline $\mathrm{xu} \varepsilon_{2}$ & [ว̌ xwغ̀] & ' 3 sg is laughing' \\
\hline $\mathrm{k} \tilde{\jmath}$ & [ذ̀nว̀mé kì̀ríbó] & 'Ọnọmẹ plants/ is planting pepper' \\
\hline sa & [àjè nă sà vè] & 'the woman is shooting me' \\
\hline
\end{tabular}

If the verb does not have an object, a suffix $-A$ (with two variants: $-\varepsilon$ after [+ATR] roots and $-a$ after [-ATR] roots) attaches to the verb root only if the root vowel is a high vowel (which becomes a glide). It is interesting to note that $[\varepsilon]$ is the [+ATR] counterpart of this suffix in Urhobo. In Degema which still has all ten vowels, the variants are [ə] with [+ATR] and [a] with [-ATR] roots. In this construction, we find again that $\left[\mathrm{e}_{2}, \mathrm{o}_{2}\right]$ behave like typical [-ATR] vowels by taking the suffix $-a$ which is the variant selected by [-ATR] roots. The fact that $[\varepsilon]$ is the [+ATR] variant of this suffix is an indication of the merging of $* / \partial /$ with $[\varepsilon]$. 
(8) a. $[+\mathrm{ATR}]$ verbs

\begin{tabular}{|c|c|c|c|}
\hline Si & mì sì̀ & [m̌r sjè] & 'I pull/ am pulling' \\
\hline$f$ & ǒ fù̃ $\tilde{\varepsilon}$ & {$\left[\begin{array}{ll}\check{\mathrm{o}} & \mathrm{f} \tilde{\mathrm{w}} \tilde{\tilde{\varepsilon}}\end{array}\right]$} & '3sg extinguishes' \\
\hline & wǒ sè & & 'you call/ are calling' \\
\hline & mi cò & & 'I steal/ am stealing' \\
\hline & wó $\gamma \overline{\tilde{\varepsilon}}_{1}$ & & 'you are being foolish' \\
\hline
\end{tabular}

b. $[-\mathrm{ATR}]$ verbs

\begin{tabular}{|c|c|c|c|}
\hline $\mathrm{rè}_{2}$ & mè $_{2}$ rià & [mě rjà] & 'I eat/ am eating' \\
\hline $\mathrm{cò}_{2}$ & ǒ cùà & [ว̌ cwà] & ' 3 sg trades/ is trading' \\
\hline & wว $\int \grave{\varepsilon}_{2}$ & & 'you sell/ are selling' \\
\hline$\approx$ & $\mathrm{mé}_{2} \mathrm{k} \overline{\tilde{j}}$ & & 'I plant/ am planting' \\
\hline sà & wว̌ sà & & 'you shoot/ are shooting \\
\hline
\end{tabular}

In (9) below, both the pronoun and the auxiliary agree with the [ATR] value of the verb root.
a. [+ATR $]$ verbs

\begin{tabular}{|c|c|}
\hline S1 & mí ź1 siغ \\
\hline fì̀ & ǒ ź́ fù்̃̀ \\
\hline $\mathrm{se}_{1}$ & wǒ źl sè \\
\hline & mi $3^{\prime} 1 \mathrm{cò}_{1}$ \\
\hline$\tilde{\tilde{\varepsilon}}_{1}$ & wǒ źl vì̃ \\
\hline
\end{tabular}
[m̌̌ źl sjè] 'I am still pulling/ writing'
[ǒ $\left.3^{\prime} 1 \mathrm{f} \tilde{w} \tilde{\tilde{\varepsilon}}\right]$ ' $3 \mathrm{sg}$ is still going out'
'you are still calling/ reading'
'I am still a thief'
'you are still having babies'
b. $[-\mathrm{ATR}]$ verbs

\begin{tabular}{|c|c|c|}
\hline 2 & [mě zé rjà] & 'I am still eating' \\
\hline & [ว̌ zé swà] & '3sg is still singing' \\
\hline 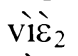 & wǒ zé vì̀ 2 & 'you are still crying' \\
\hline & 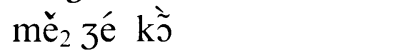 & 'I am still planting' \\
\hline
\end{tabular}

3.4. Constructions in the past tense. A sentence in the past tense is also marked by a floating high tone which is located on the final vowel of the verb root. Where the verb takes a noun object, the vowel of the verb root either become a nonsyllabic glide or deletes, depending on the first vowel's height. As a result, the tone which marks tense is realized on the initial vowel of the object. Just as in the present tense forms, verbs in the past tense also select appropriate harmonizing affixes in both subject and object positions where necessary. We note here too that whereas $\left[\mathrm{e}_{1}, \mathrm{o}_{1}\right]$ behave as nonhigh $[+\mathrm{ATR}]$ vowels, $\left[\mathrm{e}_{2}, \mathrm{o}_{2}\right]$ behave as high 
[-ATR] vowels. Similarly, $\left[\varepsilon_{1}\right]$ behaves as a $[+\mathrm{ATR}]$ vowel whereas $\left[\varepsilon_{2}\right]$ behaves as a [-ATR] vowel. A few examples are in (10) below:
a. si
[mì śi wé]
'I pulled you'
[wò kwévri]
' 2 sg poured oil'
$\mathrm{se}_{1} \quad$ [ò sé vé]
' 3 sg called me'
$\mathrm{co}_{1} \quad$ [àjè nà cékpù]
'The woman stole a bag'
$\mathrm{do}_{1}$ [wò dó ró]
'you threw it'
vi $\varepsilon_{1} \quad$ [mì vjómó]
'I gave birth to a child'
b. re ${ }_{2}$ [mè rjónć] 'I ate yam'
$\mathrm{CO}_{2}$ [àjè nà cwéki]
'the woman traded'
'you sang it'
$\mathrm{SO}_{2} \quad$ [wò só ró]
$\int \varepsilon_{2} \quad$ [o $\int^{\prime} \varepsilon$ vé
sa
[àjè nà sóhwó]
'3sg sold me'
'the woman shot someone'

If the verb does not take an object, a suffix $-r I$ (with two phonetic variants: $-r i$ with [+ATR] roots and -re with [-ATR] roots) attaches to the verb root. Here too $\left[\mathrm{e}_{2}, \mathrm{o}_{2}\right.$ ] behave like typical [-ATR] vowels while $\left[\varepsilon_{1}\right]$ behaves like a [+ATR] vowel in the selection of the affix. As the examples in (11) show, the suffix attached to high back vowels also agree in backness with the root vowel. These are yet other instances of the merging of $* / \mathrm{I}, \mathrm{U}, \mathrm{\partial} /$ with $\left[\mathrm{e}_{2}, \mathrm{O}_{2}, \varepsilon_{1}\right]$ respectively in synchronic grammar. (Note that in Isoko, the variants of this morpheme are -ri and - $r I$ respectively.)

(11) a. [+ATR] verbs

$\begin{array}{ll}\text { mi sírì } & \text { 'I pulled, I wrote' } \\ \text { wò múrù } & \text { 'you carried' } \\ \text { ò sé }{ }_{1} \text { rì } & \text { '3sg called, 3sg read' } \\ \text { mi có }{ }_{1} \text { rì } & \text { 'I stole' } \\ \text { mi ví } \varepsilon_{1} \text { rì } & \text { 'I gave birth' } \\ \text { ò } \varphi \tilde{\varepsilon}_{1} \text { rì } & \text { '3sg became wide' } \\ \text { ò xú́ } \varepsilon_{1} \text { rì } & \text { '3sg poured away' }\end{array}$


b. [-ATR] Verbs

\begin{tabular}{|c|c|}
\hline $\mathrm{mè}_{2}$ ré $_{2} \mathrm{rè}_{2}$ & 'I ate' \\
\hline wò só ${ }_{2}$ rò & '2sg sang' \\
\hline mè ví́ $\varepsilon_{2}$ rè & 'I cried' \\
\hline$\grave{j} \varphi \varepsilon_{2} \grave{\mathrm{e}}_{2}$ & '3sg urinated' \\
\hline j̀ xú $\varepsilon_{2}$ rè̀ & '3sg laughed' \\
\hline $\mathrm{mè}_{2}$ kórè & 'I planted' \\
\hline wò sárè 2 & '2sg shot' \\
\hline
\end{tabular}

3.5. Constructions in the future tense. The future tense is marked by an auxiliary which is also in two phonetic shapes: ce with [+ATR] verb roots and $c a$ with [-ATR] roots. This tense has no suffix; note that auxilaries and pronouns will harmonize as expected.

a. $[+\mathrm{ATR}]$ verbs

\begin{tabular}{|c|c|}
\hline mí cè ś $^{\prime}$ & 'I will write' \\
\hline wó ź1 cè mú & '2sg will still/ also carry' \\
\hline ó cè sé $_{1}$ & ' 3 sg will call, read' \\
\hline mí źl cè có & 'I will still/ also steal' \\
\hline wó cè $\grave{e}_{1} \gamma \tilde{\varepsilon}_{1}$ & '2sg will be foolish' \\
\hline 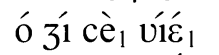 & ' 3 sg will still/ also bear (children)' \\
\hline ó ź1 cè̀ $\varphi \tilde{\varepsilon}_{1}$ & ' 3 sg will still/ also become wide' \\
\hline ó cè ${ }_{1}$ xú $\varepsilon_{2}$ & '3sg will pour away' \\
\hline
\end{tabular}

b. [-ATR] verbs

mé $_{2}$ cà ré

'I will eat'

wó zé è $_{2}$ cá ó $_{2}$

'2sg will still/ also sing'

ó zé $e_{2}$ cà víć

' 3 sg will still/ also cry'

ว́ zé $e_{2}$ cà $\varphi \tilde{\varepsilon}_{2}$

' 3 sg will still/ also urinate'

ว zé $e_{2}$ cà xúć,

mé ${ }_{2}$ cà k̃́

'3sg will also laugh'

wó cà sá

'I will plant'

'2sg will shoot'

One other phenomenon that needs to be mentioned about $[\varepsilon]$ regards its role in surface vowel hiatus. Ordinarily, vowel sequences at the phrase level are eliminated, but such sequences are optionally allowed only if the first vowel is $[\varepsilon]$, which carries a $\mathrm{L}$ tone as though there is a pause between the words. This means that $[\varepsilon]$ can either attach after a high vowel or replace a nonhigh vowel in 
such a structure, irrespective of the [ATR] requirement of the verb. This behavior of $[\varepsilon]$ is akin to that of [ə] as the vowel commonly found in unstressed syllables in languages that have it. We believe that this behavior of $[\varepsilon]$ in Urhobo is not unconnected with the merging of * ${ }^{*}$ with $\varepsilon$. The following are some examples:
a. $[+\mathrm{ATR}]$ verbs
si [mì sjê úrùhré] $\sim$ [m̌̀ sjúrùhré]
'I am pulling a rope'
$\mathrm{ku}$ [wò kwê èvri]
$\sim$ [wò kwévri]
'2sg poured oil'

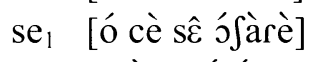
[ó cè sófàrè]
' 3 sg will call a man'
$\mathrm{do}_{1}$ [wò dê úré]
$\sim$ [wò dúré]
viغ $\varepsilon_{1}$ [mı̌ źl vjè ว́mó]
$\sim$ [mí ź́ vjómó]
'2sg threw a stick'
'I am still having babies'
b. [-ATR] verbs

\begin{tabular}{|c|c|c|}
\hline $\mathrm{re}_{2} \quad[\mathrm{mě} \mathrm{rj} \hat{\varepsilon}$ ว̀ń́] & $\sim$ [mě rjòné $]$ & 'I am eating yam' \\
\hline $\mathrm{SO}_{2} \quad$ [wò swê ùnè] & ～[wò swúnè] & '2sg sang (a song)' \\
\hline $\int \varepsilon_{2} \quad$ [mě zé $\int \varepsilon ̀$ ènmá] & ～[mě zé Sènmá] & 'I am still selling clothes' \\
\hline [mé zé cà kẽ íríbó] & ～[mé zé cà kíríbó] & 'I will also plant pepper' \\
\hline [àjè nă sê òhwó] & [àjè nă sòhwó] & $\begin{array}{l}\text { 'the woman is shooting } \\
\text { someone' }\end{array}$ \\
\hline
\end{tabular}

This takes place only before a vowel-initial object, therefore [m̌̌ sì wè] 'I am pulling you', and not *[m̌́ sjè wè].

From the foregoing, it is clear that there is consistency in the vowel behavior: $\left[\mathrm{e}_{1}, \mathrm{o}_{1}\right.$ ] always behave as nonhigh [+ATR] vowels while $\mathrm{e}_{2}, \mathrm{o}_{2}$ always behave as high [-ATR] vowels in verb roots as well as in the affixes they select. In addition, $\left[\varepsilon_{1}\right]$ always behaves as a $[+\mathrm{ATR}]$ vowel while $\left[\varepsilon_{2}\right]$ always behaves as a [-ATR] vowel both as a root vowel and in the affixes it selects. We shall now turn to the noun.

\section{The Behavior of /e, $0, \varepsilon /$ in Nouns.}

The basic structure of the Urhobo noun is disyllabic, i.e., it consists of a vowel prefix and a $-\mathrm{CV}$ or $-\mathrm{CCV}$ root. There are also many trisyllabic and a few polysyllabic nouns. Urhobo vowels are presented in the disyllabic nouns of (14) below. Note the occurrence of $\left[\mathrm{e}_{2}, \mathrm{O}_{2}\right]$ as both prefix and root vowels as well as occurrence of $\left[\varepsilon_{1}\right]$ as a $[+\mathrm{ATR}]$ root vowel. This will become clearer in the next section. 
(14) Nouns

\begin{tabular}{|c|c|c|c|}
\hline a. $[+\mathrm{AT}$ & vowels & {$[-\mathrm{AT}$} & owels \\
\hline $1 \gamma o_{1}$ & 'money' & $\mathrm{e}_{2} \mathrm{mó}$ & 'children' \\
\hline $\mathrm{e}_{1} \mathrm{bò}_{1}$ & 'sack' & $\grave{\mathrm{o}}_{2} \mathrm{~d} \grave{\varepsilon}_{2}$ & 'name' \\
\hline $\mathrm{o}_{1} \mathrm{do}_{1}$ & 'mortar' & $\grave{\varepsilon}_{2} \gamma a ̀$ & 'taboo' \\
\hline ùjù & 'louse' & ómó & 'child' \\
\hline úk $\tilde{\varepsilon}_{1}$ & 'egg' & àtỗ 2 & 'desert' \\
\hline úg $\tilde{\varepsilon}_{1}$ & 'fish trap' & $\grave{j s e ̀ ~}_{2}$ & 'lover' \\
\hline
\end{tabular}

Only a few grammatical processes affect the shape of nouns in Urhobo, the most important one being plural formation. In this section, we shall examine how nouns form their plural and how vowels behave in phrasal combinations affecting nouns. Our main focus is the behavior of $/ \mathrm{e}, \mathrm{o}, \varepsilon /$ in these constructions.

4.1. Plural formation. Generally, the process of plural formation in Edoid languages is phonologically predictable from [ATR] harmony rules, with a few exceptions. ${ }^{2}$ It involves alternating the prefix vowel of the singular noun with the plural prefix $I$ - which becomes $i$ - before [+ATR] roots and $I$ - before [-ATR] roots. It is generally easy to predict the shape of the plural noun from the prefix vowel of the singular, possibly because PE had a noun class system that became nonexistent in the synchronic system of most of the languages, and also because in harmony systems, co-occurrence restrictions enables prefix and root vowels to agree in terms of the harmony feature(s).

In Urhobo, the allomorphs are $i$ - before [+ATR] roots and $e$ - before [-ATR] roots (another line of evidence for the merging of $*[\mathrm{I}]$ with $[\mathrm{e}]$ ). The data reveal the co-occurrence of 'typical' [+ATR] vowels [e, o] with [-ATR] vowels. We find that where $[i, e, u]$ occur as prefix vowel of the singular noun, they always select [i] as the plural prefix, the variant for $[+\mathrm{ATR}]$ nouns, and where $[\varepsilon, \mathrm{a}, 0]$ occur as the singular prefix vowels, they always select [e], the variant for [-ATR] nouns. Where, however, the singular prefix is [o] it may select either [i] or [e] as the plural prefix, and there is really no way of predicting which variant will be selected. This is because [o] is ambiguous as to being $\left[\mathrm{o}_{1}\right]$ i.e. /o/ which would be in harmony with a $[+\mathrm{ATR}]$ vowel, or $\left[\mathrm{O}_{2}\right]$ i.e. $/ \mathrm{U} /$, which would be in harmony with a [-ATR] vowel. We note the absence of [e] in the prefix position of singular [-ATR] nouns. All cases of $[\mathrm{e}]$ in singular nouns found in our data belong to the

\footnotetext{
2 A few nouns which Elugbe (1973) calls "paired body parts" form their plural by changing the

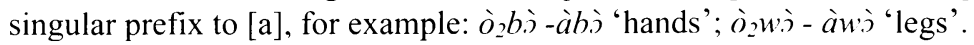


[+ATR] group. This may not be unconnected with the fact that, as has been noted by Donwa-Ifode (1989), when vowels disappear from a system, they do so first at the prefix position.

A look at the vowels of the noun root does not make the prediction of the plural form much clearer even though, as was the case with verbs, Urhobo operates a root-controlled harmony. We find that where $[\mathrm{i}, \mathrm{u}]$ occur as root vowels in the singular, the plural prefix is [i] and where $[0, a]$ occur as root vowels in the singular, the plural prefix is [e]. However, where the root vowel of the singular noun is any of $[\mathrm{e}, \mathrm{o}]$, the plural variant to be selected is unpredictable: it could be [i] or [e]. As a result, the system appears complex. Thus, the co-occurrence of vowels at both the prefix and root positions are important in selecting the plural prefix of nouns.

\begin{tabular}{|c|c|c|}
\hline \multicolumn{3}{|c|}{. $[+\mathrm{ATR}]$ Nouns } \\
\hline$S g$. & Pl. & \\
\hline ùdì & idì & 'drink' \\
\hline ùbè $_{1} k$ ũ & ìbè $e_{1} k \tilde{u}$ & 'bone' \\
\hline$\grave{o ̀}_{1} \mathrm{zé}_{1}$ & izé $_{1}$ & 'basin' \\
\hline$o_{1}$ dibó ${ }_{1}$ & '́dibó & 'banana' \\
\hline$\grave{o}_{1} \gamma r e_{1} \mathrm{sì}$ & ìréé sì & 'bush rat' \\
\hline$e_{1} b_{o_{1}}$ & íbò & 'sack' \\
\hline$e_{1} \mathrm{kpè}_{1} \mathrm{t}_{\mathrm{l}}$ & ${ }^{\prime} \mathrm{kpè̀}_{1} \mathrm{ti}$ & 'box' \\
\hline 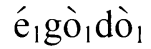 & '́gò $\mathrm{dò}_{1}$ & 'compound' \\
\hline $1 \gamma \mathrm{o}_{1}$ & $1 \gamma o_{1}$ & 'money' \\
\hline ijé $_{1} \mathrm{rè}_{1}$ & ijé $_{1} \mathrm{rè}_{1}$ & 'road' \\
\hline iríbó & iríbó $_{1}$ & 'pepper’ \\
\hline
\end{tabular}

\begin{tabular}{|c|c|c|}
\hline \\
\hline \multicolumn{3}{|c|}{$\begin{array}{l}\text { [-ATR] Nouns } \\
S g . \quad P l\end{array}$} \\
\hline$\grave{\mathrm{o}}_{2} \mathrm{~d} \grave{\varepsilon}_{2}$ & $\grave{\mathrm{e}}_{2} \mathrm{~d} \grave{\varepsilon}_{2}$ & 'name' \\
\hline$\grave{o}_{2} \varphi$ árò 2 & $\grave{e ̀}_{2} \varphi$ áròn 2 & 'face' \\
\hline $\mathrm{o}_{2} \mathrm{r} \tilde{\mathrm{z}}$ & $\mathrm{e}_{2} \mathrm{r} \tilde{\mathrm{J}}$ & 'ear' \\
\hline àtồ 2 & $\grave{\mathrm{e}}_{2} \mathrm{t}_{2}$ & 'desert' \\
\hline$\varepsilon_{2} c \varepsilon_{2}$ & $e_{2} c \varepsilon_{2}$ & 'door' \\
\hline$\grave{\varepsilon}_{2}$ yà & $\grave{e ̀}_{2} \gamma a ̀$ & 'taboo' \\
\hline غ̇jènćkpò & 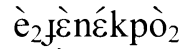 & 'tiger' \\
\hline js $\tilde{\tilde{e}}_{2}$ & $\grave{\mathrm{e}}_{2} \mathrm{Se}_{2}$ & 'lover' \\
\hline$\dot{j}_{b o ̀}^{2}$ & $\grave{\mathrm{e}}_{2} \mathrm{bò}_{2}$ & 'doctor' \\
\hline$\dot{\varepsilon}_{\text {Evé }}$ & $\grave{e ̀}_{2} v e_{2}$ & 'goat' \\
\hline 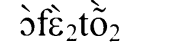 & $\grave{\mathrm{e}}_{2} f \bar{\varepsilon}_{1} \mathrm{t} \tilde{\tilde{o}}_{2}$ & 'comb' \\
\hline job̀rà & $\grave{e}_{2}$ bàrà & 'blood' \\
\hline ómó & $\mathrm{e}_{2} \mathrm{~m} \dot{ }$ & ‘child' \\
\hline àkṕś & $\grave{\mathrm{e}}_{2} \mathrm{kp} \varepsilon_{2}$ & 'lock' \\
\hline àgbàrã & $\grave{e ̀}_{2}$ gbàrã̀ & 'chair' \\
\hline
\end{tabular}

In the examples in (16) below, a surface [-ATR] vowel $[\varepsilon]$ occurs in the root with a surface $[+\mathrm{ATR}]$ prefix vowel, and the noun patterns as a $[+\mathrm{ATR}]$ noun to agree with the prefix[the prefix agrees with the root, the root does not agree with the prefix]. As mentioned earlier, $[\varepsilon]$ is absent from the prefix position of singular [+ATR] nouns. Again, this may not be unconnected with the weak prefix position and, also as mentioned earlier, in the order of vowel disappearance among Edoid languages, a disappears first. As a result, traces of a can hardly be 
expected in that position. Both our verb and noun data therefore show that the sound has merged with $[\varepsilon]$ and that when it patterns as a $[+\mathrm{ATR}]$ vowel, it is $\left[\varepsilon_{1}\right]$.

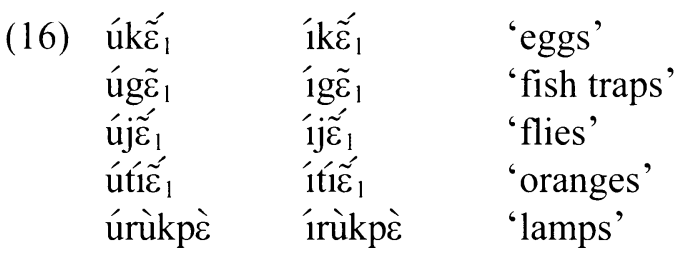

It is necessary to mention here, too, that the low [-ATR] vowel [a] sometimes co-occurs with and patterns as a [+ATR] vowel as we show in (17). A similar occurrence has been reported in a number of Niger-Congo languages and has been traced to the merging of $* / \partial /$ with [e], [ $\varepsilon$ ] and [a] (cf. Elugbe 1983, Donwa-Ifode 1989, Williamson 2004). The following are some examples.

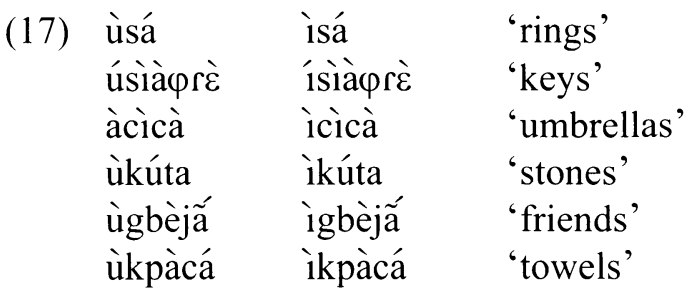

4.2. Phrasal combinations. One other factor that is germane to our argument in establishing the existence of abstract underlying vowels $* / \mathbf{I}, \mathrm{U} /$ that have become surface $[e, o]$ can be seen when nouns occur in phrasal combinations. As with verbs, in phrasal combinations involving Noun + Noun, our data show that when $\left[\mathrm{e}_{2}, \mathrm{o}_{2}\right]$ occur as final vowels of $\mathrm{N}_{1}$, they consistently trigger glide formation in the fashion of the typical high vowels $[\mathrm{i}, \mathrm{u}]$, rather than undergoing vowel elision as the nonhigh vowels $\left[\mathrm{e}_{1}, \mathrm{o}_{1}\right]$ do.

(18) a. $V_{1}$ as a high vowel

$$
\begin{aligned}
& \text { ùdì }+ \text { àmè }_{2} \text { [ùdjámè] 'palm wine' } \\
& \grave{e}_{1} k u ̀+\grave{e}_{1} k u ̀ \text { [èkwékù] 'only trouble' } \\
& \grave{\varepsilon}_{2} v e_{2}+\grave{j o o ̀}_{2} \text { [Èvjóvò] 'one goat' } \\
& \text { àsồ }{ }_{2}+\check{e}_{2} \text { rà [àswérà] 'three nights' }
\end{aligned}
$$


b. $\mathrm{V}_{1}$ as a nonhigh vowel

$$
\begin{array}{lll}
\text { izé }_{1}+\text { itè }_{1} \text { té }_{1} & \text { [izítèté] } & \text { 'small basins' } \\
\text { úkó }_{1}+\text { àmè̀ }_{2} & \text { [úkámè] } & \text { 'a cup of water' } \\
\text { é }_{2} \text { mó }+\check{e}_{2} \text { rà } & \text { [émérà] } & \text { 'three children' }
\end{array}
$$

In the forms in (19) below, we present sequences with $\left[\mathrm{e}_{2}, \mathrm{o}_{2}\right]$ with regard to both glide formation and plural formation. The data shows that the nouns with $\left[\mathrm{e}_{2}, \mathrm{O}_{2}\right]$ as root vowels become glides at phrasal level (meaning that they are high vowels) and they also select the plural prefix [e] (meaning that they are [-ATR]

\begin{tabular}{|c|c|c|c|c|}
\hline 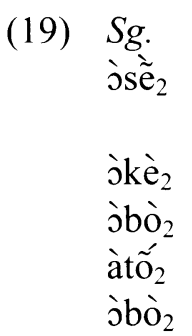 & $\begin{array}{l}P l . \\
\grave{\mathrm{e}}_{2} \mathrm{Se}_{2} \\
\check{\varepsilon} \grave{n e ̀ ~}_{2}\end{array}$ & 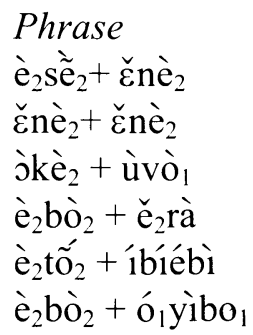 & $\begin{array}{l}\text { Spoken form } \\
\text { [èsǰ̌nè] } \\
\text { [ènjéné] } \\
\text { [’̉kjúvò] } \\
\text { [èbwěra] } \\
\text { [ètwíbjibì] } \\
\text { [èbwóyibó] }\end{array}$ & $\begin{array}{l}\text { Gloss } \\
\text { 'four lovers' } \\
\text { 'in fours' } \\
\text { 'dry season' } \\
\text { 'three doctors' } \\
\text { 'black chewing sticks' } \\
\text { 'western doctors' }\end{array}$ \\
\hline
\end{tabular}
vowels), an indication that they are underlying */I, U/ which have become surface $\left[\mathrm{e}_{2}, \mathrm{o}_{2}\right]$ respectively.

\section{Summary and Conclusion.}

Our study has shown that the synchronic vowel system of Urhobo has abstract underlying vowels resulting from historical vowel merging, which still influence vowel behavior in the synchronic grammar of the language. There are abstract high [-ATR] vowels */I, U/ that have become surface $\left[\mathrm{e}_{2}, \mathrm{o}_{2}\right]$ respectively and abstract underlying $* / \partial /$ that has become $\left[\varepsilon_{1}\right]$ (and possibly [a]). The merging of vowels is complete on the surface in the synchronic system, and an absolute neutralization rule has nullified any distinction between the vowels with respect to their source.

Using glide formation, which affects high vowels, plural formation, which affects nouns, and affixation, which induces harmonic co-occurrence restrictions, we have been able to establish that Urhobo has at the underlying level the ten vowels $* / \mathrm{i}, \mathrm{I}, \mathrm{e}, \varepsilon, \partial, \mathrm{a}, \supset, \mathrm{o}, \mathrm{U}, \mathrm{u} /$, while at the surface/phonetic level, there are only seven vowels, without [I, ə, U]. The abstract underlying high [-ATR] vowels */I, U/ have merged with mid [+ATR] vowels /e, o/ respectively. In addition, facts from affixation reveal the existence of the abstract underlying low [+ATR] vowel */a/ that has neutralized with $/ \varepsilon /$, making it be the [+ATR] counterpart of [a] as a 
suffix vowel. The result is that surface $e, o, \varepsilon$ each displays both expected and unexpected vowel behavior. The only way to tell which vowel underlies $e, o, \varepsilon$ is to observe them in [ATR]-harmony or height-revealing environments. We also noted that there are many nouns in which a typical [-ATR] vowel/a/ occurs in both prefix and stem positions in some nouns that select the [+ATR] plural prefix, a situation that suggests the merging of $* / a /$ with $/ \mathrm{a} /$, as has been reported in some Niger-Congo languages.

Thus, just like Okpe and Uvwiẹ (Omamor 1988), Urhobo phonemic vowels can be grouped on the basis of both vowel height and [ATR] harmony. A study such as this is necessary for phonotactic reasons and for a better understanding of the vowel system but as has been rightly pointed out by Elugbe (1991), any attempt to write the language using the phonemically 'accurate' vowels would create problems for the native speaker because it is at variance with his linguistic instincts. The native speaker knows whether the [e] or [o] in a word would undergo glide formation or not, so that the use of the seven vowels for writing the language is appropriate and in consonance with his competence and innate knowledge of his language. Judging from the speech patterns of young Urhobo speakers, [ATR] harmony is on its way out of the system, because it is not reflected with much seriousness in their speech forms. For instance it is common to hear young speakers say [mì $\gamma^{\prime}$ ró] instead of [mè $\gamma^{\prime}$ ró] 'I formally received him' with the subject pronoun being [+ATR] rather than [-ATR] to agree with the verb. 


\section{References}

Aziza, Rose O. 1994. "Vowel harmony in Urhobo". Nigerian Language Studies 2: 1-7.

Aziza, Rose O. 1997. Urhobo Tone System. Ibadan: University of Ibadan, PhD dissertation.

Aziza, Rose O. 2002. "Nasality in Urhobo: an autosegmental perspective". Journal of West African Languages 29.2: 11-21.

Donwa-Ifode, Shirley. 1989. "Prefix vowel reduction and loss of noun class distinction: the Edoid case". Afrika und Übersee 72: 229-253.

Elugbe, Ben. 1973. A Comparative Edo Phonology. Ibadan: University of Ibadan, $\mathrm{PhD}$ dissertation.

Elugbe, Ben. 1983. "The vowels of proto-Edoid". Journal of West African Languages 13: 79-89.

Elugbe, Ben. 1989. Comparative Edoid: Phonology and Lexicon. Delta Series No. 6. Port Harcourt: University of Port Harcourt Press.

Elugbe, Ben. 1991. "The limits of accuracy in the design of orthographies". Journal of West African Languages 21.1: 49-54.

Fulop, Sean A., Ethelbert Kari \& Peter Ladefoged. 1998. "An acoustic study of the tongue root contrast in Degema vowels. Phonetica 55: 80-98.

Hoffman, Carl 1973. "Okpe: a nine vowel language with only seven vowels". Research Notes, University of Ibadan 61.3: 79-111.

Kelly, John 1969. "Vowel patterns in the Urhobo noun". Journal of West African Languages 6.1:21-26.

Lindau, Mona. 1975. "Features for vowels". UCLA Working Papers in Phonetics 30: 16-21. 
Omamor, Augusta P. 1973. "Uvwiẹ: a case of vowels merging". Research Notes, University of Ibadan 61-3: 112-143.

Omamor, Augusta P. 1988. "Okpẹ and Uvwiẹ: a case of vowel harmony galore". Journal of West African Languages 18.1: 47-64.

Welmers, William E. 1969. "Structural notes on Urhobo". Journal of West African Languages 6.2: 85-107.

Williamson, Kay 1983. "Vowel merger in harmony languages". Journal of the Linguistic Association of Nigeria 2: 61-82.

Williamson, Kay. 2004. "Typical vowel systems and processes in West African Niger-Congo languages”. Journal of West African Languages 30.2: 127-142.

Department of Languages and Linguistics

Delta State University

Abraka, Nigeria

roaziza12@yahoo.com [received Sept. 8, 2007

accepted June 12, 2008] 
